\title{
PREFERENSI ATLET OKU SELATAN TERHADAP CITA RASA OLAHAN IKAN MUJAIR DENGAN METODE C-SAT (CUSTOMER SATISFICATION)
}

\section{PREFERENCE OF OKU SELATAN ATHELETE TO TILAPIA FISH PRODUCT FLAVOUR BY C-SAT (CUSTOMER SATISFICATION) METHODE}

\author{
Melati Pratama ${ }^{1 *}$ \\ ${ }^{1}$ Program Studi Seni Kuliner, Politeknik Pariwisata Palembang, Sumatera Selatan. \\ *Korespondensi : melatipratama07002@gmail.com
}

\begin{abstract}
Tilapia is one of the fresh water fish, and one of commodites that was cultivated by OKU Selatan specialy Ranau lake. Around the Ranau lake, tilapia usually was processed to grilled tilapia fish, turmeric seasoning, pindang Palembang and fried fish. The tilapia products had off-falvour so OKU Selatan athete ate other food like fried rice, fried chicken and tempeh, soto, instan noodles and etc. The aims for this research was to identified preference of OKU Selatan athlete to tilapia product, and analyzied flavor preference of OKU Selatan athlete based on five senses and cooking method. The data was calculated by $C$-Sat (Customer Satisfication). The results showed that the highest preference of $O K U$ Selatan athelete to tilapia product at grilled tilapia such as 6.4 point and the lowest preference at Pindang such as 4.8 point. The highest preference of OKU Selatan to sensation taste at umami such as 9.9 point and the lowest at the bitter taste such as 1.5 point. The highest prefence of OKU Selatan to tilapia taste due processing at fried tilapia processed such as 9.8 point and the lowest at boiled tilapia processed such as 5.2 point. Athelete of OKU Selatan most prefer to tilapia that has umami sensation by fryied processed.
\end{abstract}

Keywords : flavor, OKU Selatan athlete, tilapia product, C-Sat

\section{Pendahuluan}

Mujair adalah salah satu komoditi perikanan yang hidup di air tawar, termasuk ke dalam golongan flat fish karena memiliki bentuk tubuh yang pipih dengan panjang $40 \mathrm{~cm}$. Bersisik kecil-kecil, tubuh memiliki garis vertical, sirip ekor memiliki garis berwarna merah. Berwarna coklat, abu-abu hingga hitam. Warna ikan mujair tergantung pada habitatnya (Webb et al., 2017). Ikan mujair segar mengandung zat gizi protein sebanyak 18.7 gram, lemak sebanyak 1 gram, kalsium sebanyak 96 mg, dan besi sebanyak 1.5 mg (Depkes RI, 2004).

Ikan mujair dapat dibedakan menjadi beberapa jenis diantaranya adalah mujair biasa, mujair merah dan mujair albino. Jenis ikan mujair yang disering dikonsumsi adalah ikan mujair biasa. Umumnya, ikan mujair dibudidayakan di kolam air tawar dan tambak air payau. Salah satu daerah yang membudayakan ikan ini adalah Danau Ranau, Oku selatan. Di daerah ini, jumlah produksi ikan mujair adalah sebesar 4,302 ton per tahun (Utmoko et al., 2007).

Ikan mujair umumnya diolah menjadi ikan bakar, ikan bumbu kuning, pindang dan digoreng. Berdasarkan penelitian Sonjaya et al. (2019), konsumsi ikan mujair 
oleh atlet OKU Selatan berkisar 5-10\%. Rendahnya konsumsi mujair oleh atlet OKU Selatan disebabkan karena olahan ikan mujair yang tidak praktis dan cita rasa yang biasa sehingga untuk mencukupi kebutuhan gizi dan kalorinya, atlet OKU Selatan mengkonsumsi nasi goreng, ayam dan tempe goreng, soto, mi instan, telur dadar dan bayam sebagai lauk pauk.

Menurut Drummond (2017), banyak alasan untuk seseorang memilih suatu makanan untuk dikonsumsi atau tidak. Salah satu faktornya adalah cita rasa. Cita rasa adalah rasa dan aroma yang merupakan kombinasi dari kelima indera dan menjadi hal yang penting dalam makanan, karena pentingnya cita rasa ikan mujair terhadap kesukaan atlet OKU Selatan, maka peneliti tertarik untuk melakukan kajian lebih lanjut tentang preferensi atlet OKU Selatan terhadap cita rasa olahan ikan mujair.

Preferensi atlet OKU selatan terhadap cita rasa olahan ikan mujair dalam penelitian ini dikaji menggunakan uji C-Sat. Uji C-Sat dipilih karena menurut Ngo (2015) uji ini berfokus pada kepuasan pelanggan, dalam penelitian ini atlet. C-Sat (Customer Satisfication Ratings) adalah istilah yang mencakup berbagai survey dan pertanyaan umpan balik; C-Sat dirancang untuk mengukur seberapa senang/suka/puas seseorang terhadap produk yang ada. Variable yang dinilai pada penelitian ini adalah tingkat kesukaan atlet terhadap olahan ikan mujair yang sudah ada (Pindang, ikan bakar, ikan bumbu kuning dan ikan goring), rasa dan teknik pengolahan ikan mujair. Responden diminta untuk menilai sendiri tingkat kesukaan mereka terhadap variabel yang ditentukan.

Tujuan penelitian ini adalah untuk mengidentifikasi selera para atlet OKU Selatan terhadap olahan ikan mujair yang sudah ada, menganalisis cita rasa yang lebih disukai atlet OKU Selatan berdasarkan kelima indera melalui berbagai metode pengolahan.

\section{Metode Penelitian}

Metode yang digunakan dalam penelitian ini adalah deskriptif yang bersifat kuantitatif, dimana data hasil penilaian dari responden terhadap cita rasa ikan mujair dengan berbagai teknik pengolahan dideskripsikan atau digambarkan.

\section{Jenis dan sumber data}

Data yang digunakan dalam penelitian ini adalah data primer dan data sekunder.

a. Data primer diambil melalui observasi dan wawancara yang dilakukan terhadap atlet OKU Selatan mengenai makanan yang mereka sukai, dan para pedagang kuliner di sekitar Danau ranau. Penelitian diawali dengan melakukan identifikasi mengenai selera para atlet terhadap olahan mujair yang sudah ada diantaranya Pindang, mujair bumbu kuning, mujair bakar dan mujair goreng, dilanjutkan dengan analisis cita rasa yang lebih disukai berdasarkan kelima indra dan teknik pengolahan. Wawancara mendalam dilakukan pada masing-masing atlet.

b. Data sekunder yang digunakan adalah referensi jurnal/hasil penelitian mengenai pengolahan ikan mujair. 


\section{Pendekatan Penelitian}

Metode penelitian yang digunakan adalah metode penelitian deskriptif kuantitatif yang melalui observasi dan wawancara. Pendekatan survei dilakukan dengan pengajuan pertanyaan mengenai preference masing-masing atlet terhadap cita rasa olahan mujair berdasarkan kelima indera dan teknik pengolahan. Responden pada penelitian ini adalah gabungan beberapa cabang olahraga yang diambil melalui KONI sebanyak 15 orang.

\section{Teknik Pengambilan Sampel}

Sampel diambil sebanyak 15 atlet terdiri dari atlet balap sepeda, bola tangan, taekwondo, renang dan dayung. Kelima cabang olahraga ini dipilih sebagai sampel karena 5 cabang olah raga ini yang sedang berkembang di KONI OKU Selatan dan memiliki jumlah atlet terbanyak di KONI OKU Selatan dibanding cabang lainnya. Berdasarkan penelitian Sonjaya et al. (2019), kebutuhan gizi dan energy antar cabang olahraga tidak berpengaruh nyata. Hal ini yang melatarbelakangi kebutuhan protein antar kelima cabang olahraga dianggap sama. Teknik pengambilan sampel dilakukan secara probability sampling dengan teknik pengambilan sampel acak berdasar area (Cluster random sampling). Cluster Sampling adalah teknik sampling secara berkelompok. Pengambilan sampel jenis ini dilakukan berdasar kelompok / area tertentu. Tujuan metode Cluster Random Sampling antara lain untuk meneliti tentang suatu hal pada bagian-bagian yang berbeda di dalam suatu instansi. Pada penelitian ini masing-masing cabang olahraga diwakili oleh 3 orang atlet.

\section{Teknik Pengolahan dan Analisis Data}

Data diolah dan dianalisis menggunakan statistik inferensial. Menurut Sugiyono (2010), statistik inferensial adalah statistik yang digunakan untuk menganalisis data sampel dan hasilnya akan digeneralisasikan untuk populasi dimana sampel diambil. Data yang diperoleh disunting yaitu dengan memeriksa apakah seluruh daftar pertanyaan yang dikembalikan responden telah sesuai dengan pertanyaan yang diajukan dan lengkap, kemudian data diberi kode dan dikelompokkan sesuai dengan tingkat kesukaan berdasarkan variabel. Hasil pengelompokkan kemudian dihitung menggunakan uji C-Sat. C-Sat dihitung dengan menghitung rata-rata nilai suka atau tidak suka dari suatu penilaian.

Berikut adalah rumus perhitungan C-Sat menurut Ngo (2015)

C-Sat Average $=$

$[(1 * n 1)+(2 * n 2)+(3 * n 3)+(4 * n 4)+(5 * n 5)+(6 * n 6)+(7 * n 7)+(8 * n 8)+(9 * n 9)+(10 * n 10)$ ]$/ \mathrm{n}$

\begin{tabular}{ccccccccccc} 
& $\begin{array}{c}\text { Sangat } \\
\text { Tidak } \\
\text { Suka }\end{array}$ & & & & & & & & $\begin{array}{c}\text { Sangat } \\
\text { Suka }\end{array}$ \\
\hline C-Sat & 1 & 2 & 3 & 4 & 5 & 6 & 7 & 8 & 9 & 10 \\
\hline & $\mathrm{n} 1$ & $\mathrm{n} 2$ & $\mathrm{n} 3$ & $\mathrm{n} 4$ & $\mathrm{n} 5$ & $\mathrm{n} 6$ & $\mathrm{n} 7$ & $\mathrm{n} 8$ & $\mathrm{n} 9$ & $\mathrm{n} 10$ \\
\hline
\end{tabular}


Data yang telah di kalkulasi menggunakan C-Sat kemudian digambarkan di Spider Web ntuk dianalisis. Identifikasi dan analisis preference atlet OKU Selatan didasarkan pada batasan nilai 5.6.

\section{Hasil dan Pembahasan}

\section{Jumlah responden, Usia dan Jenis Kelamin}

\section{Responden}

Berdasarkan hasil observasi dan pengambilan sampel menggunakan cluster random sampling, maka masing-masing responden untuk tiap cluster adalah sebanyak 3 orang. Banyaknya responden dari masing-masing cluster (cabang olahraga) dapat dilihat pada Tabel 1.

Tabel 1. Jumlah sampel masing-masing cluster/cabang olahraga

\begin{tabular}{lc}
\hline Nama cabang olahraga & Jumlah sampel (orang) \\
\hline Balap sepeda & 3 \\
Bola tangan & 3 \\
Taekwondo & 3 \\
Renang & 3 \\
Dayung & 3 \\
\hline Total & 15 \\
\hline
\end{tabular}

Usia

Berdasarkan hasil wawancara yang dilakukan terhadap 15 atlet KONI OKU Selatan diperoleh atlet OKU Selatan berusia 15 - 16 tahun. Persentase usia atlet OKU Selatan dapat dilihat pada Gambar 1.

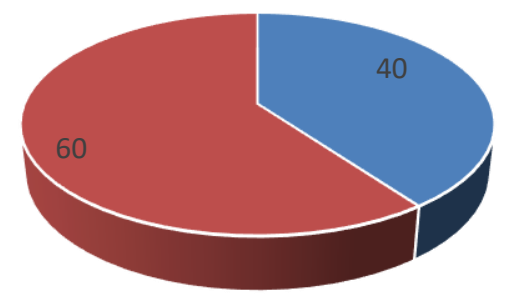

- Usia 15 tahun (\%) - Usia 16 tahun (\%)

Gambar 1. Persentase usia atlet OKU Selatan

Atlet OKU Selatan yang menjadi responden berusia 15 tahun adalah sebanyak $40 \%$, dan berusia 16 tahun sebanyak $60 \%$. Hal ini disebabkan karena program KONI OKU Selatan adalah melakukan pembibitan dan pembinaan sejak usia dini. Jenis Kelamin

Persentase jenis kelamin responden atlet OKU Selatan dapat dilihat pada Gambar 2. 


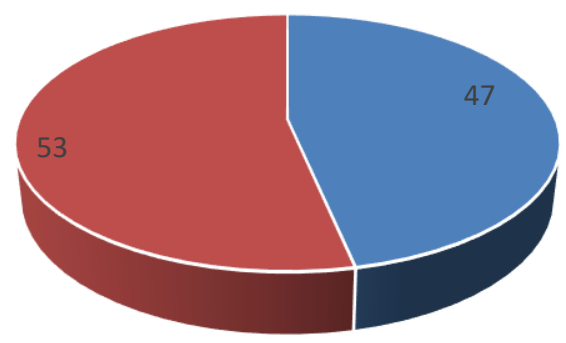

- Perempuan (\%) - Laki-laki (\%)

Gambar 2. Persentase jenis kelamin atlet OKU Selatan

Berdasarkan hasil wawancara diperoleh data responden atlet KONI OKU Selatan 53\% berjenis kelamin laki-laki, dan $47 \%$ berjenis kelamin perempuan.

Selera atlet OKU Selatan terhadap olahan ikan mujair (Pindang, mujair bakar, bumbu kuning dan mujair goreng)

Tingkat kesukaan atlet terhadap empat jenis olahan ikan mujair berdasarkan uji C-Sat dapat dilihat pada Gambar 3, Gambar 4, Gambar 5 dan Gambar 6.

Sangat

Penilaian terhadap Pindang

Sangat

Tidak

Suka

Suka

\begin{tabular}{|l|l|l|l|l|l|l|l|l|l|l|}
\hline C-Sat & 1 & 2 & 3 & 4 & 5 & 6 & 7 & 8 & 9 & 10 \\
\hline
\end{tabular}

Gambar 3. Tingkat kesukaan atlet terhadap Pindang

\begin{tabular}{l|c|c|c|c|c|c|c|c|c|c|}
\multicolumn{1}{cc}{} & $\begin{array}{c}\text { Sangat } \\
\text { Tidak } \\
\text { Suka }\end{array}$ \\
\hline C-Sat & 1 & 2 & 3 & 4 & 5 & 6 & 7 & 8 & 9 & $\begin{array}{c}\text { Sangat } \\
\text { Suka }\end{array}$ \\
\hline
\end{tabular}

Gambar 4. Tingkat kesukaan atlet terhadap Ikan bakar

\begin{tabular}{c|c|c|c|c|c|c|c|c|c|c|}
\multicolumn{1}{cc}{} & $\begin{array}{c}\text { Sangat } \\
\text { Tidak } \\
\text { Suka }\end{array}$ & \multicolumn{1}{c}{$\begin{array}{c}\text { Penilaian terhadap Ikan bumbu } \\
\text { kuning }\end{array}$} & $\begin{array}{c}\text { Sangat } \\
\text { Suka }\end{array}$ \\
\hline C-Sat & 1 & 2 & 3 & 4 & 5 & 6 & 7 & 8 & 9 & 10 \\
\hline
\end{tabular}

Gambar 5. Tingkat kesukaan atlet terhadap ikan bumbu kuning 


$\begin{array}{ccc}\begin{array}{c}\text { Sangat } \\ \text { Tidak }\end{array} & \text { Penilaian terhadap Ikan goreng } & \text { Sangat } \\ \text { Suka }\end{array}$

Suka

\begin{tabular}{|l|l|l|l|l|l|l|l|l|l|l|}
\hline C-Sat & 1 & 2 & 3 & 4 & 5 & 6 & 7 & 8 & 9 & 10 \\
\hline
\end{tabular}

Gambar 6. Tingkat kesukaan atlet terhadap ikan goreng

Hasil perhitungan menggunakan metode C-Sat diketahui bahwa atlet OKU Selatan memberikan penilaian kesukaan tertinggi pada ikan mujair yang dibakar yaitu sebesar 6,4, dan terendah pada ikan mujair yang dipindang yaitu sebesar 4,8. Pindang adalah salah satu makanan khas sumatera selatan, pindang yang terdapat di OKU Selatan berbeda dengan pindang pada umumnya yang di awetkan dengan diberi penambahan garam. Pindang yang terdapat di OKU Selatan adalah pindang yang dimasak dengan bumbu masak tradisional seperti kunyit, lengkuas, bawang, dan kemangi sehingga memiliki aroma yang kuat. Pindang memiliki rasa asin, manis, asam dan pedas yang kuat serta memiliki aroma khas ikan . Pindang umumnya dikonsumsi dalam keadaan hangat bersama nasi putih (Budisetyorini et al., 2019). Pindang memiliki nilai $\mathrm{C}$-sat terendah dibanding lainnya hal itu disebabkan Pindang merupakan makanan berkuah, aroma amis ikan juga larut ke dalam kuah pindang sehingga menurunkan selera atlet.

Menurut Worthington (2000), Ada beberapa faktor yang mempengaruhi tingkat kesukaan seseorang terhadap suatu makanan yaitu :

a. Usia

Usia mempengaruhi sensitivitas reseptor perasa. Usia atlet OKU Selatan berkisar antara 15-16 tahun. Usia 15-16 tahun merupakan kategori remaja. Sensitivitas indera pengecap dipengaruhi oleh usia. Sensitivitas indera pengecap tinggi pada usia anak-anak dan menurun pada manula. Berdasarkan penelitian Hartono (2014), absolute threshold/ambang batas senstivitas anak remaja sebesar $8.8 \times 10^{-5} \pm 4.55 \times 10^{-9} \mathrm{M}$ sedangkan dewasa sebesar $1,39 \times 10^{-4} \pm 1,56 \times 10^{-9} \mathrm{M}$. Tingginya sensitivitas tersebut menyebabkan aroma amis pada ikan sangat mudah terdeteksi, sehingga menurunkan prefernsi atlet OKU Selatan dan menyebabkan para atlet tersebut memilih dalam makanan.

b. Kebiasaan Makanan

Faktor selanjutnya yang mempengaruhi nafsu makan anak remaja adalah kebiasaan orang tua dalam menyiapkan makanan bagi anaknya. Menurut Sinaga (2016), umumnya para orang tua lebih memilih makanan cepat dan ringkas untuk disajikan, terutama makanan untuk di pagi hari, misalnya telur, nasi goreng dan lainnya.

\section{Preferensi atlet OKU Selatan terhadap rasa sensasi}

Menurut Drummond (2017), Lidah manusia dapat mendeteksi 4 rasa sensasi primer yaitu manis, asam, asin dan pahit, serta satu rasa sensasi sekunder yaitu 
umami yang dominan ditemukan pada L-Glutamat. Penilaian preference atlet terhadap kelima rasa sensasi berdasarkan analisis uji C-Sat dapat dilihat pada Gambar 7, Gambar 8, Gambar 9, Gambar 10, dan Gambar 11.

\begin{tabular}{|c|c|c|c|c|c|c|c|c|c|c|} 
& $\begin{array}{c}\text { Sangat } \\
\text { Tidak } \\
\text { Suka }\end{array}$ & $\begin{array}{c}\text { Penilaian terhadap rasa } \\
\text { manis }\end{array}$ & $\begin{array}{r}\text { Sangat } \\
\text { Suka }\end{array}$ \\
\hline C-Sat & 1 & 2 & 3 & 4 & 5 & 6 & 7 & 8 & 9 & 10 \\
\hline
\end{tabular}

Gambar 7. Tingkat kesukaan atlet terhadap rasa manis

Sangat
$\begin{gathered}\text { Tidak } \\
\text { Suka }\end{gathered}$
\begin{tabular}{|c|c|c|c|c|c|c|c|c|c|c|}
\hline C-Sat & 1 & 2 & 3 & 4 & 5 & 6 & 7 & 8 & 9 & 10 \\
\hline
\end{tabular}

Gambar 8. Tingkat kesukaan atlet terhadap rasa asin

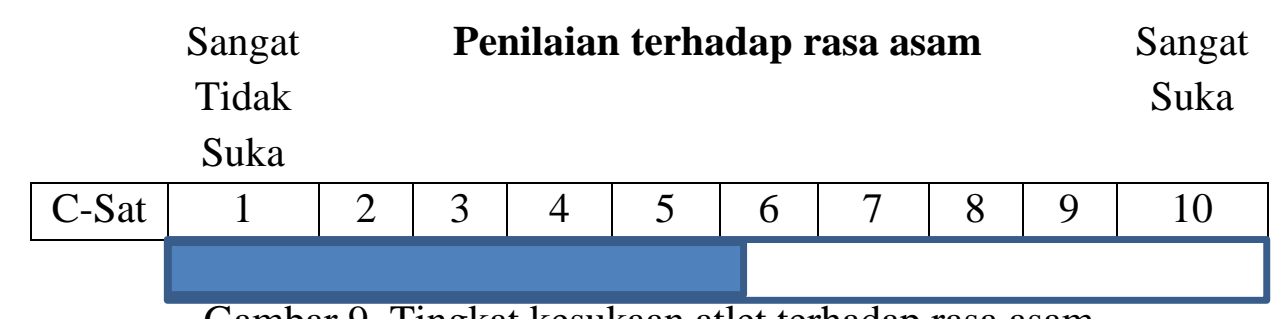

Gambar 9. Tingkat kesukaan atlet terhadap rasa asam

\begin{tabular}{|c|c|c|c|c|c|c|c|c|c|c|}
\hline & $\begin{array}{c}\text { Sangat } \\
\text { Tidak } \\
\text { Suka }\end{array}$ & & & ilai & ter & lap & a p & & & $\begin{array}{c}\text { Sangat } \\
\text { Suka }\end{array}$ \\
\hline C-Sat & 1 & 2 & 3 & 4 & 5 & 6 & 7 & 8 & 9 & 10 \\
\hline
\end{tabular}

Gambar 10. Tingkat kesukaan atlet terhadap rasa pahit

\begin{tabular}{|c|c|c|c|c|c|c|c|c|c|c|}
\hline & $\begin{array}{l}\text { Sangat } \\
\text { Tidak } \\
\text { Suka }\end{array}$ & & & Peni & $n t$ & da & & & & $\begin{array}{c}\text { Sangat } \\
\text { Suka }\end{array}$ \\
\hline C-Sat & 1 & 2 & 3 & 4 & 5 & 6 & 7 & 8 & 9 & 10 \\
\hline
\end{tabular}

Gambar 11. Tingkat kesukaan atlet terhadap rasa umami

Berdasarkan kelima rasa sensasi, diperoleh bahwa atlet cenderung menyukai makanan yang bersifat umami, manis dan asin. Hasil perhitungan menggunakan metode C-Sat menunjukkan bahwa atlet OKU Selatan memberikan penilaian 
kesukaan tertinggi terhadap rasa umami yaitu sebesar 9,9 dan terendah pada rasa pahit yaitu sebesar 1,5.

Umami merupakan rasa yang bersumber dari monosodium glutamate (MSG) dan ribonukleotida seperti garam 5-inosin-monofosfat (IMP) serta 5-guaninmonofosfat (GMP). Glutamate adalah salah satu asam amino yang umumnya banyak terdapat didalam daging, buahan, sayuran, ikan, dan lainnya (Winarno, 2008).

Hasil penelitian menunjukkan bahwa preferensi atlet OKU Selatan paling tinggi terhadap rasa sensasi umami. Hal itu disebabkan karena glutamate pada rasa umami dapat menyeimbangkan rasa makanan, selain itu menurut Winarno (2008) MSG dapat meningkatkan cita rasa yang diinginkan dengan mengurangi rasa yang tidak diinginkan seperti rasa bawang yang tajam, mengurangi rasa pahit dan menyebabkan sel reseptor rasa lebih peka sehingga menikmati rasa dengan lebih baik.

Umami bukan perpaduan antara keempat rasa dasar yaitu manis, asin, asam dan pahit (Kurihara, 2013). Umami terbentuk dari adanya pemecahan protein ikan menjadi asam amino glutamate. Pemecahan asam amino glutamate dapat terjadi jika konsentrasi garam dan asam yang terdapat di dalam ikan rendah. Hasil penelitian Adawiyah dan Setiawan (2017) menunjukkan nilai ambang deteksi rasa umami dari MSG tinggi pada konsentrasi garam yang rendah. Hal tersebut seiring dengan hasil penelitian Thariq et al. (2014), ikan dengan konsentrasi garam $20 \%$ memiliki kadar glutamate tertinggi. Konsentrasi garam dan asam yang tinggi pada ikan menyebabkan perlambatan pemecahan protein selama pengolahan.

\section{Preferensi Atlet OKU Selatan terhadap rasa sensasi akibat pengolahan}

Ada banyak metode pengolahan yang dapat digunakan untuk mengolah ikan mujair. Beberapa diantaranya adalah boiled, steam, fried, dan grilled. Menurut Atmoko dan Krestanto (2017), boiled adalah proses pengolahan makanan di dalam air mendidih atau memasak makanan berbasis pada cairan. Steam adalah proses pengolahan lembab dengan panas dari uap panas. Fried adalah metode pengolahan makanan ke dalam minyak atau lemak, dan grilled adalah metode pengolahan makanan yang melibatkan panas langsung. Sumber panas yang dapat digunakan adalah listrik, gas dan kayu.

Penilaian preference cita rasa atlet OKU Selatan dilkukan terhadap keempat metode pengolahan makanan digambarkan pada Gambar 12, Gambar 13, Gambar 14, Gambar 15.

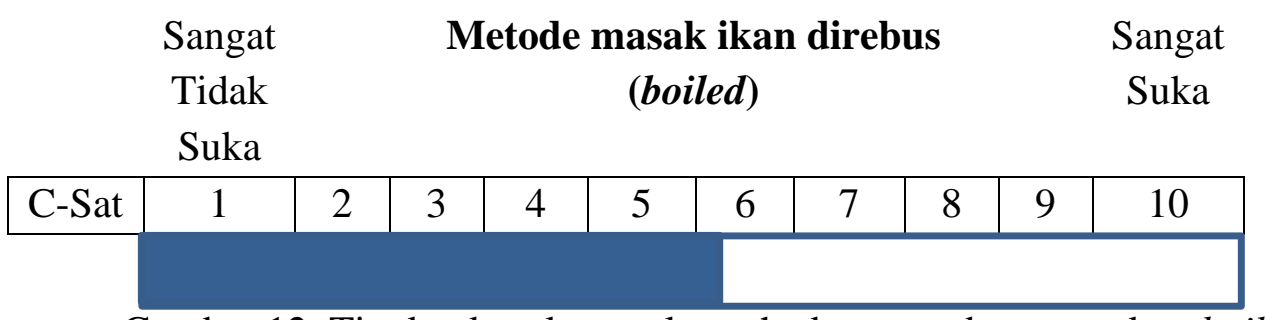

Gambar 12. Tingkat kesukaan atlet terhadap metode pemasakan boiled 


\begin{tabular}{|c|c|c|c|c|c|c|c|c|c|c|}
\hline \multicolumn{2}{|c|}{$\begin{array}{c}\text { Sangat } \\
\text { Tidak } \\
\text { Suka }\end{array}$} & & \multicolumn{6}{|c|}{$\begin{array}{c}\text { Metode masak ikan dikukus } \\
\text { (steamed) }\end{array}$} & & $\begin{array}{c}\text { Sangat } \\
\text { Suka }\end{array}$ \\
\hline C-Sat & 1 & 2 & 3 & 4 & 5 & 6 & 7 & 8 & 9 & 10 \\
\hline
\end{tabular}

Gambar 13. Tingkat kesukaan atlet terhadap metode pemasakan Steamed

\begin{tabular}{|c|c|c|c|c|c|c|c|c|c|c|}
\hline \multicolumn{2}{|c|}{$\begin{array}{l}\text { Sangat } \\
\text { Tidak } \\
\text { Suka }\end{array}$} & & \multicolumn{6}{|c|}{$\begin{array}{c}\text { Metode masak ikan digoreng } \\
\text { (fried })\end{array}$} & & $\begin{array}{c}\text { Sangat } \\
\text { Suka }\end{array}$ \\
\hline C-Sat & 1 & 2 & 3 & 4 & 5 & 6 & 7 & 8 & 9 & 10 \\
\hline
\end{tabular}

\begin{tabular}{l|c|c|c|c|c|c|c|c|c|c|} 
& $\begin{array}{c}\text { Sangat } \\
\text { Tidak } \\
\text { Suka }\end{array}$ & \multicolumn{1}{c}{$\begin{array}{c}\text { Metode masak ikan dibakar } \\
\text { (grilled) }\end{array}$} & $\begin{array}{c}\text { Sangat } \\
\text { Suka }\end{array}$ \\
\hline C-Sat & 1 & 2 & 3 & 4 & 5 & 6 & 7 & 8 & 9 & 10 \\
\hline
\end{tabular}

Gambar 15. Tingkat kesukaan atlet terhadap metode pemasakan grilled

Berdasarkan penelitian diperoleh nilai preference pengolahan ikan mujair tertinggi pada ikan mujair yang diolah dengan cara digoreng/fried yaitu sebanyak 9,8 dan terendah pada ikan mujair yang diolah dengan cara direbus/boiled yaitu sebanyak 5,2. Preferensi atlet OKU Selatan tertinggi terdapat pada metode pengolahan fried. Hal itu disebabkan menurut Ratnaningsih et al. (2007), minyak yang digunakan dalam penggorengan memiliki multifungsi yaitu sebagai media transfer panas antara makanan dan penggorengan, dan minyak berkontribusi terhadap tekstur dan cita rasa, serta menurut Aladedunye dan Przybylski (2009) minyak memberi kerenyahan pada tekstur. Pengolahan makanan menggunakan boiled dan steam tidak menggunakan minyak, serta pada pengolahan ikan mujair menggunakan metode grilled hanya menyebabkan bagian ikan terluar yang terbakar karena menurut Atmoko dan Krestano (2017) hal tersebut bertujuan agar lemak di dalam ikan berkurang. Komponen preferensi sensasi rasa dan metode pengolahan digambarkan ke dalam spider web yang dapat dilihat pada Gambar 16. 


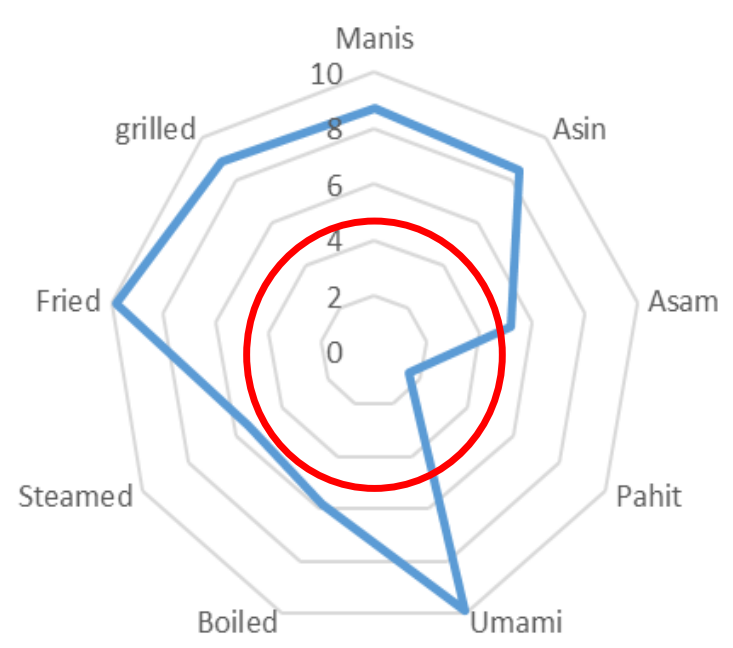

Gambar 16. Spider web preferensi atlet OKU Selatan terhadap sensasi dan metode pengolahan ikan mujair

Berdasarkan Gambar 16, spider web menunjukkan preferensi atlet OKU selatan terhadap olahan ikan mujair adalah pada rasa umami dengan metode pengolahan ikan yang digoreng (fried). Hal tersebut disebabkan metode pengolahan fried dapat meningkatkan kandungan glutamat pada ikan mujair. Hal ini seiring dengan penelitian Utami et al. (2016) yang menunjukkan bahwa ikan seluang yang digoreng memiliki kandungan asam glutamate sebesar $3.9 \%$ atau meningkat sebesar 2.65 sebelum ikan tersebut dilakukan pengolahan. Sedangkan untuk ikan seluang yang direbus (boiled) mengandung asam glutamate sebesar $2.4 \%$ dan dikukus (steam) sebesar 2.5\%.

Berdasarkan angka perhitungan C-Sat dan spider web, strategi yang diperlukan untuk mengolah ikan mujair untuk menu para atlet adalah dengan membuat menu yang memiliki karakteristik cita rasa manis atau asin, dengan campuran rasa manis dan asin yang berupa umami. Dengan metode memasak digoreng (fried) dan dibakar (grilled). Karena rasa manis, asin dan umami yang diolah pada ikan selain memberikan cita rasa pada ikan juga dapat menurunkan aroma amis pada ikan. Strategi karekteristik pengolahan fried dan grilled menjadi pilihan dalam menyusun menu untuk para atlet. Hal ini karena dengan metode fried aroma amis pada ikan akan terikat ke dalam minyak, serta metode grilled pada ikan dapat merubah amis pada ikan menjadi aroma baru.

\section{Kesimpulan}

Berdasarkan hasil penelitian dapat disimpulkan bahwa atlet OKU Selatan memiliki preferensi yang rendah terhadap olahan pindang dan bumbu kuning ikan mujair karena aroma amis yang sangat mudah terdeteksi pada kedua olahan tersebut. Preferensi atlet OKU selatan tinggi pada ikan mujair yang memiliki sensasi rasa umami. Rasa umami dapat menurunkan aroma amis. Salah satu metode olahan yang dapat meningkatkan rasa umami adalah frying (penggorengan). 


\section{Daftar Pustaka}

Adawiyah DR, Setiawan F. 2017. Ambang deteksi dan preferensi rasa umami dalam model pangan. Jurnal Teknologi dan Industri Pangan. 28(1): 55-61.

Aladedunye FA, Przybylski R. 2009. Degradation and nutritional quality changes of oil during frying. Jurnal of American Oil Chemist's Society. 86: 149-156.

Atmoko TPH, Krestanto H. 2017. Profesionalisme chef dalam pengolahan dan meningkatkan kualitas makanan di Cavinton hotel Yogyakarta. Jurnal Khasanah Ilmu. 8(2): 60-69.

Budisetyorini B, Suherlan H, Reyaan A. 2019. Pengaruh kunjungan wisatawan terhadap peningkatan jumlah pengusaha kuliner dan inovasi produk kuliner di Kota Palembang. Laporan penelitian (integrated research) Sekolah tinggi pariwisata bandung. Bandung.

Direktorat Gizi Departemen Kesehatan RI. 2004. Daftar komposisi bahan makanan. Jakarta : Bhratara.

Drummond KE. 2017. Food Nutrition Based on Diet. Jerman: Oxford

Hartono G. 2014. Deteksi ambang batas rasa asam ditinjau dari tingkatan usia dan jenis kelamin di Daerah pesisir Pemalang dan Semarang. Skripsi Fakultas Teknologi Pangan Universitas Katolik Soegijapranata. Semarang.

Kurihara K. 2013. Umami the fifth basic taste: history of studies on receptor mechanisms and role as a food flavor. Journal of BioMed Research International. 1(1) : 1-10.

Ngo VM. 2015. Measuring customer satisfication : A literature review. Prosiding Internatioan Financial of firms in Sci. 1638-1655.

Ratnaningsih, Rahardjo B, Suhargo. 2007. Kajian penguapan air dan penyerapan minyak pada penggorengan ubi jalar (Lpomoea batatas L.) dengan metode deep fat-frying. Jurnal Agritechnology 27(1). 27-32.

Sinaga. 2016. Pengaruh pola konsumsi makan cepat saji terhadap kadar kolesterol siswa kelas XI SMA Negeri 8 dan SMA Pangudi Luhur Yogyakarta. Skripsi pendidikan biologi universitas Sanata Dharma Yogayakarta. Yogyakarta.

Sonjaya AM, Pratama M, Yansyah M. 2019. Desain menu breakfast para atlet sebagai supporting sport tourism di Oku Selatan. Laporan Penelitian Kelompok Politeknik Pariwisata Palembang. Politeknik Pariwisata Palembang.

Sugiyono. 2010. Statistika Untuk Penelitian. Bandung: Alfabeta.

Thariq AS, Swastawati F, Surti T. 2014. Pengaruh perbedaan konsentrasi garam pada peda ikan kembung (Rastrelliger neglectus) terhadap kandungan asam glutamate pemberi rasa gurih (umami). Jurnal Pengolahan dan Bioteknologi Hasil Perikanan. 3(3):104-111.

Utami P, Lestari S, Lestari SD. 2016. Pengaruh metode pemasakan terhadap komposisi kimia dan asam amino ikan seluang (Rasbora argyrotaenia). Jurnal Teknologi Hasil Perikanan. 5(1):73-84. 
Utmoko AD, Wibowo A, Mohtar H. 2007. Pengelolaan sumber daya perikanan di kabupaten Ogan Kemering Ulu (OKU) Selatan provinsi Sumatera Selatan. Badan perencana pembangunan daerah kabupaten ogan komering ulu selatan.

Webb A, Satrio R, Nadia N. 2017. Morfologi Ikan Mujair. Buletin Perikanan. Bandung

Winarno FG. 2008. Kimia pangan dan gizi. Mbrio Press. Bogor.

Worthington BS. 2000. Nutrition throughout the life cycle. United Mcgraw-hill book companies Inc. 